\title{
Comparative Assessment on the Ecologic and Economic Impact of New Road Technologies Integrating Reclaimed Asphalt Pavement
}

\author{
Alina Mihaela Nicuțăa ${ }^{1, a}$, Radu Andrei ${ }^{2, b}$, Mihai Budescu ${ }^{3, c}$ \\ ${ }^{1,2,3}$ Faculty of Civil Engineering and Building Services, Technical University "Gheorghe Asachi", \\ lasi, 700050, Romania, \\ aalinanicuta@yahoo.com, ${ }^{b}$ radu.andrei.d@gmail.com, mbsinfex@yahoo.com
}

Keywords: comparative analysis, environmental and economic impact, reclaimed asphalt pavement (RAP), asPECT software.

\begin{abstract}
The features and interdependences between environment and economics, connected to the construction of asphalt road pavements, can be evaluated by a wide diversity of decision support tools. The characteristics of these tools and the complementary informative system provide complex assessments. Their final purpose is to ensure an optimum sustainable constructive solution. The present paper aims, along a comparative analysis, to evaluate the environmental and economic impact resulted from the construction of road pavements with asphalt mixtures that integrate different percentages of RAP. The objective was to highlight the characteristics, benefits and limitations of these procedures and conclude on their usage and viability. The evaluation was performed according to LCA and LCC methodology and facilitated by asPECT computer software. Performing this study was intended to facilitate the researchers and practitioners analytical choice and to offer a personal overview on the topic.
\end{abstract}

\section{Introduction}

The present paper has the objective to evaluate, along a comparative perspective, specific to three European countries, the ecologic and economic impact resulted from the usage of flexible asphalt pavements integrating different percentages of Reclaimed Asphalt Pavement (RAP). The analysis was performed based on two corresponding methodologies namely: Life Cycle Assessment (LCA) and Life Cycle Cost Assessment (LCCA). In order to complete the evaluation information obtained during two different post-doctoral research mobility stages at Technical University of Vienna and Universidad Politecnico de Madrid has been used.

The feedback received from the host entities facilitated the comparative evaluation based on LCA and LCC methodologies, thus offering a complex overview on the topic of environmental and economic interdependences. In order to address the complexity of current project works and the newly sustainability issues, the research institutes have looked for a solution that can offer an extended overview on the topics. By considering and analyzing separately the sustainability components in correlation to the construction ones, this solution can improve time viability of the analysis and provide the best alternatives on the matter. The solution has been offered by the group of Life Cycle methodologies, either assessing ecologic, economic or social components particularized on domains. A statistical study, conducted in several institutes showed an increased interest and acceptability for this methodology, in the last years, even more due to the fact that the users have strongly interconnected the theoretical component to the computer science side, creating a wide diversity of software. Their purpose is to facilitate the research work and allow complex evaluations. For the present paper the best suiting software was considered to be asPECT, a program developed by the researchers from Transport Research Laboratory (TRL), England, particularized on performing LCA on asphalt pavements. This software provides information on the environmental impact, expressed as $\mathrm{kg}$ equivalent $\mathrm{CO}_{2}$ emissions, resulted during the process of construction of flexible asphalt pavements.

In order to provide a solution to the environmental impact issue, for the analysis several road pavement construction alternatives have been considered, extended from traditional asphalt pavement compositions to new compositions that integrate different percentages of RAP. 
The results were observed from a comparative perspective for different countries, different types of flexible asphalt pavements and different percentages of RAP integrated into traditional mixture compositions. The results, approached from the environmental and economic perspective, highlighting the potential improvements for different countries, different types of flexible asphalt pavements and different percentages of RAP integrated into traditional mixture compositions.

Next to the assessment of environmental impact, the evaluation the economic perspective has been considered, due to the interdependences between these two and the importance of cost component for every sector. Finally, the economic features have been evaluated based on the principles of LCC methodology, applied to the particular case of flexible asphalt pavements.

\section{Life cycle perspective on Reclaimed Asphalt Pavement (RAP)}

Recycling of used materials associated with the concept of product system is increasing as importance. LCA methodology evaluates the complex process of recycling in the marketplace [5]. This way, practitioners can envisage different scenarios for a product's end of life treatment, like reuse, recycling, incineration or land filling. The objective is to design products that can be highly recycled in order to reduce the future ecologic burden and lower the production costs.

The road construction sector puts a lot of effort into enabling the recyclability of used materials and reducing the environmental impact associated with the product systems life cycle.

Due to an important increase in the number of lane-km of paved road in all the states, $94 \%$ of those using asphalt mixture, constructing and maintaining the network had implicitly economic and environmental consequences [10]. Transportation agencies in cooperation with researchers in the area have worked out on finding the way to approach these problems.

A solution was found in the materials recyclability process. Since 1970 a campaign of recycling the old asphalt material was started, known as RAP. Envisioning the benefits offered by this material, Mike Acott, former president of NAPA declared that "RAP is a treasure trove of pre-processed road building material". Due to the increase in the cost of asphalt, the scarcity of quality aggregates and the need to protect the environment, his opinion is shared by many and the use of RAP has become extensively favored over "virgin" materials $[2,15,3]$.

RAP can be recycled and incorporated in different types of mixes like Hot Mix Asphalt (HMA), Warm Mix Asphalt (WMA) or Cold Mix Asphalt (CMA) or as aggregate in granular or stabilized base materials [4] together with "virgin" materials. The technological development in plants and equipments was the factor that made possible the increase of RAP usage in asphalt mixtures up to $50 \%$ or more [11].

Currently, the asphalt paving industry is a leader in the usage of recycled products, RAP being the most reused material in the world, with values nearly twice as big as the combined total of recycled paper, glass, aluminum and plastic [10], the main user being USA. This attitude was influenced by the benefits resulted from preserving the natural environment, reducing wastes and providing cost effective materials [4].

Incorporating RAP into new asphalt mixtures starts with the asphalt mixture end of life. When a road pavement reaches the end of its service life, the materials can still maintain considerable value. During the process of asphalt pavement milling or demolition results a significant quantity of construction waste [19]. The extracted materials can be recycled, resulting RAP, or, and here can be mentioned the particular case of Romania, disposed in a landfill. Finding an alternative to landfill has economic and environmental benefits. These consist in avoiding fees charged to dump material and conserving the asphalt binders and aggregates.

A factor which highly contributed to the extended usage of RAP and helped overcoming its limitations was the development in the equipments and techniques. As a result, the recycling and the creation of the new asphalt mixtures can be performed on site or at plant and can be specific to different types of flexible asphalt mixtures. 


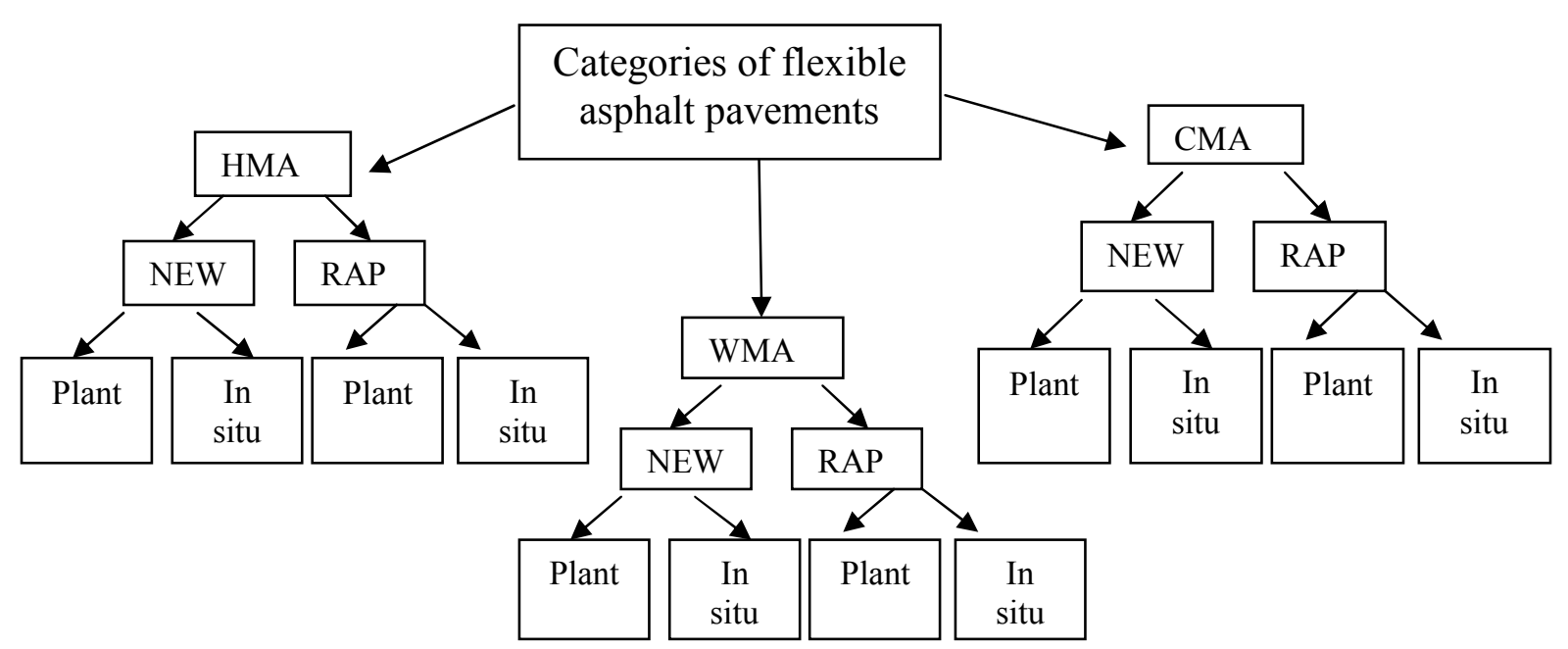

Figure 1: Categories of flexible asphalt pavements, traditional and recycled compositions

The production process of a recycled asphalt mixture consists of crushing, screening and mixing the RAP with "virgin" materials, binder or additives. The most important feature in the production is to ensure an adequate mixing between "virgin" materials and RAP, so that the final product performs as well as, or better than, the traditional one [14].

Almost all national transport agencies now allow the use of RAP and many are routinely using mixes with $20 \%$ to $25 \%$ RAP or more. Still, the percentage of RAP used in different states from the USA ranks to higher values of up to 70--80\% (60\% Florida, 70\% Arkansas) [4]. Europe follows the same sustainable trend as the USA. The asphalt recyclability started more than 30 years ago so that, currently, more than 50 million tons of materials are being reused annually. For countries like United Kingdom $30 \%$, Austria $20 \%$, Spain $20 \%$, the use of RAP is common practice. However, there are still several European countries where there is hardly any reuse of RAP.

Many countries have inserted restrictions in their regulations regarding the usage of RAP in order to avoid durability problems. Other agencies have an aggressive approach by increasing the allowable percentage of RAP in order to fully exploit the technology.

In search for a maximum exploitation of RAP benefits, a lot of studies with the objective of finding material replacements or additives that can increase the quality and performance of asphalt pavements using RAP have been implemented. An alternative to HMA has been considered the Warm Mix Asphalt (WMA) due to its advantages consisting in cutting down the amount of energy required, decrease in emissions and aging of asphalt binder during production and extending the pavement life. Due to lower temperature necessary for production and construction of WMA, RAP can be used in higher percentages.

For a better performance of $100 \%$ RAP mixes, the studies have identified the need to use, along very low amounts of "virgin" materials, different additives. Tao and Mallick (2008) make reference to some examples of additives, which have already proven their feasibility, like Sasobit ${ }^{\circledR}$ and Advera ${ }^{\circledR z e o l i t e ~[13] . ~ D u e ~ t o ~ t h e s e ~ c o m p o u n d s ~ t h e ~ R A P ~ m i x e s ~ s h o w e d ~ i n c r e a s e d ~ w o r k a b i l i t y, ~}$ higher moduli, and strengths [18].

\section{Assessment of Environmental Impact Associated with Asphalt Mixtures Integrating RAP}

Approaching a process from the environmental impact point of view implies obtaining information on materials, products and processes, comparing the available alternatives and choosing the right strategy in order to reduce the value of emissions resulted.

Particularizing the matter on road pavement construction, one of the impact features under evaluation must be computing the carbon footprint associated to the process, expressed as $\mathrm{kg} \mathrm{CO}_{2} \mathrm{e}$ emissions [16]. 
In the present paper, in order to obtain reliable results, the evaluation was performed gradually based on LCA methodology and the "cradle to site" perspective. The approach was conditioned by the process complexity, standing for energy and materials consumption, exploited labor force, production activity, transportation and emissions during each phase of the product system life cycle [9]. The TRL product, asPECT computer software, proved to be extremely useful along the analysis process [1].

The objective was to perform several comparisons related to different national approches of RAP integration in asphalt mixtures and to the environmental impact associated to the traditional versus recycled flexible asphalt mixture compositions.

The evaluation has been performed in a "cradle to site" perspective, related to a road pavement structure consisting of three layers build with traditional and recycled materials. Previous studies evaluated the environmental impact using LCA methodology for all three layers (BA 16, BAD 25 and $\mathrm{AB}$ 2) and compared, from this point of view, the traditional and recycled asphalt mixture compositions [12]. In the present paper the assessment focuses more on the integration of different percentages of RAP into the asphalt mixture $(20 \%, 40 \%, 60 \%$ and $75 \%)$ and their comparative overview. The analysis uses some of the input data previously considered in the study, like "virgin materials" production categories and rates or energy consumption associated to the process. The current study focuses on one asphalt layer, BA16, traditional and recycled asphalt compositions.

Based on the analysing performed on the environmental impact of several asphalt mixture composition, that integrate RAP in different percentages, can be concluded on the sequential decrease of this impact, computed as $\mathrm{kg} \mathrm{CO}_{2} \mathrm{e}$ emissions per ton of mixture.

Table 1 below makes a presentation of the traditional (BA 16) and recycled $\left(\mathrm{BA}^{\mathrm{r}} 16\right)$ asphalt compositions expressed as percentage of integrated materials.

Table 1: BA 16 and $\mathrm{BA}^{\mathrm{r}} 16$ asphalt mixture composition

\begin{tabular}{|l|l|l|l|l|l|l|l|l|l|}
\hline \multicolumn{2}{|c|}{ BA 16 } & \multicolumn{2}{|c|}{$\mathbf{B A}^{\mathbf{r}} \mathbf{1 6 - 2 0 \%}$} & \multicolumn{2}{c|}{ BA $^{\mathbf{r}} \mathbf{1 6}-\mathbf{4 0 \%}$} & \multicolumn{2}{c|}{$\mathbf{B A}^{\mathbf{r}} \mathbf{1 6 - 6 0 \%}$} & \multicolumn{2}{c|}{ BA $^{\mathbf{r}} \mathbf{1 6 - 7 5 \%}$} \\
\hline & $\%$ & & $\%$ & & $\%$ & & $\%$ & & $\%$ \\
\hline Bitum & 6.0 & Bitum & 4.0 & Bitum & 4.0 & Bitum & 3.0 & Bitum & 2.0 \\
\hline Filler & 10.4 & Filler & 8.4 & Filler & 6.4 & Filler & 4.4 & Filler & 3.0 \\
\hline $\begin{array}{l}\text { Chippings } \\
4-8\end{array}$ & 14.1 & $\begin{array}{l}\text { Chippings } \\
4-8\end{array}$ & 12.1 & $\begin{array}{l}\text { Chippings } \\
4-8\end{array}$ & 12.1 & $\begin{array}{l}\text { Chippings } \\
4-8\end{array}$ & 10.1 & $\begin{array}{l}\text { Chippings } \\
4-8\end{array}$ & 10.0 \\
\hline $\begin{array}{l}\text { Chippings } \\
8-16\end{array}$ & 24.4 & $\begin{array}{l}\text { Chippings } \\
8-16\end{array}$ & 20.4 & $\begin{array}{l}\text { Chippings } \\
8-16\end{array}$ & 12.4 & $\begin{array}{l}\text { Chippings } \\
8-16\end{array}$ & 7.4 & $\begin{array}{l}\text { Chippings } \\
8-16\end{array}$ & - \\
\hline $\begin{array}{l}\text { Crushed } \\
\text { sand }\end{array}$ & 45.1 & $\begin{array}{l}\text { Crushed } \\
\text { sand }\end{array}$ & 35.1 & $\begin{array}{l}\text { Crushed } \\
\text { sand }\end{array}$ & 25.1 & $\begin{array}{l}\text { Crushed } \\
\text { sand }\end{array}$ & 15.1 & $\begin{array}{l}\text { Crushed } \\
\text { sand }\end{array}$ & 10.0 \\
\hline & & RAP & 20.0 & RAP & 40.0 & RAP & 60.0 & RAP & 75.0 \\
\hline
\end{tabular}

The mixtures under consideration integrate RAP in percentages of $20 \%, 40 \%, 60 \%$ and $75 \%$. The annual production in plant was considered 375.000 tons per year, with a production rate of $199 \mathrm{t} / \mathrm{h}$. Based on the compositions, the associated environmental impact has been evaluated, expressed as $\mathrm{kg} \mathrm{CO}_{2} \mathrm{e}$ emissions per ton of asphalt mixture, using the principles of LCA methodology and asPECT computer software [1].

Since previous studies made refference on three, most common, asphalt mixtures used by the local road construction company, BA 16, BAD 25 and AB 2, the case study presented here under evaluation can be extended to the other types of asphalt mixtures, using a similar approach [12].

The results, obtained during the evaluation, have been introduced, in resume, in table 2 below. The objective of this analysis was to highlight the decrease of environmental impact as correspondence to the increase of RAP percentage. As it can be seen in the table, the impact is divided on several features. Of high interest are the values presented in the last column, that present, in numbers, the decrease of environmental impact correlated with the increase in the percentage of RAP included in the composition. The main component that sustains the usage of RAP is the decrease in the transportation sector from $20 \%$ to $75 \%$ by $60.5 \%$. 
Table 2: Environmental impact associated with BA 16 including different percentages of RAP

\begin{tabular}{|c|c|c|c|c|c|c|}
\hline $\begin{array}{c}\text { Asphalt } \\
\text { mixture } \\
\text { composition }\end{array}$ & $\begin{array}{c}\text { Virgin mix } \\
\mathrm{kg} \\
\mathrm{CO}_{2} \mathrm{e} / \mathrm{t}\end{array}$ & $\begin{array}{c}\mathrm{RAP} \\
\text { saving } \\
\mathrm{kg} \mathrm{CO} \mathrm{CO}_{2} \mathrm{e} / \mathrm{t}\end{array}$ & $\begin{array}{c}\text { Transport } \\
\mathrm{kg} \mathrm{CO}_{2} \mathrm{e} / \mathrm{t}\end{array}$ & $\begin{array}{c}\text { Heating } \\
\mathrm{kg} \mathrm{CO}_{2} \mathrm{e} / \mathrm{t}\end{array}$ & $\begin{array}{c}\text { Non heating } \\
\mathrm{kg} \mathrm{CO}_{2} \mathrm{e} / \mathrm{t}\end{array}$ & $\begin{array}{c}\text { Total } \\
\mathrm{kg} \mathrm{CO}_{2} \mathrm{e} / \mathrm{t}\end{array}$ \\
\hline $\mathrm{BA}^{\mathrm{r}} 16-20 \%$ & 45.26 & 5.29 & 117.89 & 3.56 & 22.03 & 183.35 \\
\hline $\mathrm{BA}^{\mathrm{r}} 16-40 \%$ & 47.25 & 6.44 & 97.45 & 3.56 & 22.03 & 163.86 \\
\hline $\mathrm{BA}^{\mathrm{r}} 16-60 \%$ & 47.22 & 6.30 & 78.33 & 3.56 & 22.03 & 144.85 \\
\hline $\mathrm{BA}^{\mathrm{r}} 16-75 \%$ & 48.65 & 6.70 & 46.54 & 3.56 & 20.98 & 113.02 \\
\hline $\mathrm{BA} 16$ & & & & & & 201.53 \\
\hline
\end{tabular}

If we compare the recycled compositions with the value registered for the traditional BA 16 asphalt mixture, that is $201,53 \mathrm{~kg} \mathrm{CO}_{2} \mathrm{e} / \mathrm{t}$, it can be concluded on the importance of environmental impact. The results, as percentual value, show a decrease of:

$>10,63 \%$ of environmental impact from $\mathrm{BA}^{\mathrm{r}} 16-20 \%$ to $-40 \%$,

$>11,60 \%$ of environmental impact from $\mathrm{BA}^{\mathrm{r}} 16-40 \%$ to $-60 \%$,

$>21,97 \%$ of environmental impact from $\mathrm{BA}^{\mathrm{r}} 16-60 \%$ to $-75 \%$,

$>43,9 \%$ of environmental impact from $\mathrm{BA}^{\mathrm{r}} 16-75 \%$ to BA 16 .

The present paper wishes to extend the previuos analysis by using the feedback obtained in two research mobility stages in different agencies from European Universities in Vienna and Madrid.

Their focus was on the production process and usage of other asphalt mixtures categories that could integrate RAP in higher percentages and in the same time to comply with the technical features. The attention was capted by a comparison between Hot Mix Asphalt (HMA), Warm Mix Asphalt (WMA) and Cold Mix Asphalt (CMA) and the possibility to best recycle each of these types of asphalt mixtures [6].

According to statistical information offered by European Asphalt Pavement association (EAPA) related to the total production of HMA, WMA and CMA, the values of interest for the current evaluation have been identified [20]. These are presented in table 3, expressed in million tons for the time period 2006-2011 and table 4, time sequence 2009 - 2011, expressed in tons. The information was limited to three countries of interest to the current paper, Austria, Spain and Romania, specifing also the European and world leader in production.

Table 3: HMA and WMA production in million tons for 2006-2011

\begin{tabular}{|c|c|c|c|c|c|c|}
\hline \multirow{2}{*}{ Country } & \multicolumn{6}{|c|}{ HMA and WMA mil.ton/year } \\
\cline { 2 - 7 } & 2006 & 2007 & 2008 & 2009 & 2010 & 2011 \\
\hline Austria & 10 & 9.5 & 9.5 & 9 & 8.2 & 8.0 \\
\hline Romania & 2.8 & 3.2 & 3.3 & 3.6 & 3.2 & 3.6 \\
\hline Spain & 43.4 & 49.9 & 42.3 & 39.0 & 34.4 & 29.3 \\
\hline $\begin{array}{c}\text { European leader - } \\
\text { Germany }\end{array}$ & 57 & 51 & 51 & 55 & 45 & 50 \\
\hline World leader - USA & 500 & 500 & 440 & 324 & 326 & 332 \\
\hline
\end{tabular}

Table 4: WMA and CMA production in tons

\begin{tabular}{|c|c|c|c|c|}
\hline \multirow{2}{*}{ Country } & \multirow{2}{*}{ WMA / 2011 } & \multicolumn{3}{|c|}{ CMA tons/year } \\
\cline { 3 - 5 } & & 2009 & 2010 & 2011 \\
\hline Austria & 0.0 & 20000 & 10000 & 20000 \\
\hline Romania & 0.0 & 13000 & 22000 & 13000 \\
\hline Spain & 0.126 & 275000 & 185000 & 200000 \\
\hline European leader & France 1.259 & \multicolumn{3}{|c|}{ France $\sim 1500000$} \\
\hline World leader & USA 70.600 & \multicolumn{3}{|c}{ Mexico $~ 3000000$} \\
\hline
\end{tabular}


It can be observed that generally, the world leader in the production of asphalt mixtures is the USA. This is mainly due to the large distances the government has to cover and the diversity of climatological areas to comply with. As it can be seen in table 4, Mexico is the main producer of CMA mainly because this suits best to the particularities of the country. As for Europe, Germany and France are mostly involved in the process.

The data obtained during the researches performed in Spain and Austria brought into light a certain difference between the theoretical and practical approach of RAP integration into asphalt mixtures. The general conclusion was that both countries integrate RAP into currently used asphalt mixtures in a percentage of $10-20 \%$. Contrary to Austria, in the last years Spain has experimented some road pavements with a higher percentage of RAP, reaching even $50 \%$, with very good results untill now, as mentioned by professor Juan Gallego at the Technical University in Madrid. In Spain, the reasons for producing low quantities of asphalt pavements integrating RAP were considered to be the economic crisis, that generated decreases in all sectors, but also diminuishing of high quality natural resources. Austria does not confront the crisis as bad as Spain and they still have high quality "virgin" materials. In their case the government and ecologistic agencies implied as compulsory the use of RAP into asphalt mixtures. Table 5, shows some figures of interest releted to the issue of RAP usage in different countries [20].

Table 5: Recycling process in asphalt mixtures sector

\begin{tabular}{|c|c|c|c|c|}
\hline \multirow{2}{*}{ Country } & \multirow{2}{*}{$\begin{array}{c}\text { Available } \\
\text { reclaimed } \\
\text { asphalt }\end{array}$} & $\begin{array}{c}\text { HMA }+ \\
\text { WMA }\end{array}$ & $\begin{array}{c}\text { Half Warm } \\
\text { Recycling }\end{array}$ & Cold Recycling \\
\hline Austria & 55000 & 90 & - & 5 \\
\hline Romania & 13000 & 60 & 15 & 25 \\
\hline Spain & 1350000 & 73 & - & 27 \\
\hline $\begin{array}{c}\text { European leader - } \\
\text { Germany }\end{array}$ & 14000000 & 84 & - & 16 \\
\hline World leader - USA & 71400000 & 84 & 6 & 10 \\
\hline
\end{tabular}

Once again the world leader is USA, which considers RAP the solution for material scarcity and costs reduction issues. In Europe, the countries approach the recyclability feature based on their financial disponibilities and available natural resources. Countries with reduced natural resources will try to find economic and eco-friendly alternatives.

\section{Economic Approach Associated with Asphalt Mixtures Integrating RAP}

Every productive decision is strongly correlated to the economic component. The road construction sector doesn't make an exception to this rule. The approach of recyclability issue in the production sector implies identifying the associated advantages and disadvantages, necessary investments and future profits.

In the current paper, the economic component has been evaluated based on LCC methodology towards identifying the sectors where savings corresponding to each methodological phase in a "cradle to site" perspective can be obtained.

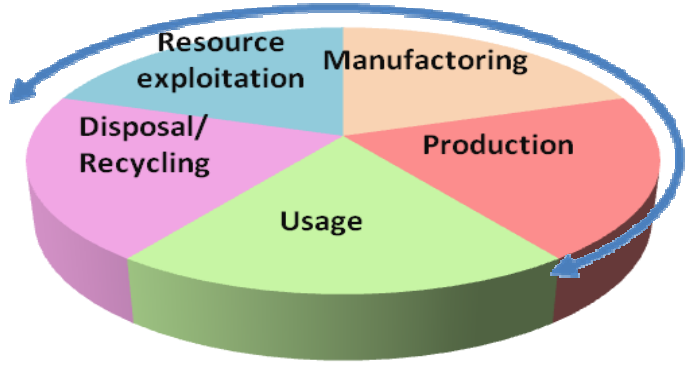

Figure 2: "Cradle to site" perspective in LCA methodology 
The main components that can bring economic savings are the energetic sources used along the entire process of production, from basic exploitation to site laying and compacting. For example, an important asphalt plant located in Madrid, Spain, area Arganda del Rey, which has daily production of $350 \mathrm{t} / \mathrm{h}$, mentioned obtaining important saving due to the use of butane gas for the production process instead of fuel. This plant has also made improvements in technical equipments in order to produce asphalt mixtures that incorporate RAP. The director of Asphalts and Constructions ELSAN Company, mentioned savings obtained due to less equipment used, fewer personnel, a reduced quantity of fuel [21].

Statistics offered by Federal Highway Administration estimate values of \$224 million savings resulted from the usage of RAP. A clear example is the State of Florida, where the highway agency integrates a value of $75 \%$ RAP into the asphalt mixtures.

The following two tables show the cost savings obtained by different government agencies in USA due to the usage of RAP in the production of asphalt mixtures and associated material cost savings [17].

Table 6: Agency Cost Savings

\begin{tabular}{|c|c|}
\hline Agency & $\begin{array}{c}\text { Average Savings } \\
\mathbf{\%}\end{array}$ \\
\hline Florida & $24-26$ \\
\hline Georgia & $4-8$ \\
\hline New York & 20 \\
\hline Wisconsin & $10-13$ \\
\hline FHWA & $1-30$ \\
\hline US Corps of Engineers & 16 \\
\hline
\end{tabular}

Table 7: Material Cost Savings

\begin{tabular}{|c|c|c|c|}
\hline $\begin{array}{c}\text { RAP } \\
\mathbf{\%}\end{array}$ & Cost /ton & $\begin{array}{c}\text { Saving } \\
\text { \$/ton }\end{array}$ & $\begin{array}{c}\text { Saving } \\
\mathbf{\%}\end{array}$ \\
\hline 0 & 11,9 & - & - \\
\hline 20 & 10,26 & 1,64 & 14 \\
\hline 30 & 9,44 & 2,46 & 21 \\
\hline 40 & 8,62 & 3,28 & 28 \\
\hline 50 & 7,8 & 4,1 & 34 \\
\hline
\end{tabular}

A general comparison between RAP and "virgin" materials usage showed a value of $8,20 \$ / t$ saving. This way for an asphalt mix integrating $20 \%$ RAP, the producers can obtain a $1,5 \$ / t$ saving [17].

Savings can result also from the usage of equipment for in situ road construction works using RAP, eliminating this way the costs associated with stockpiling, handling and inventorying RAP [11]. This might mean savings in fuel consumption and environmental benefits due to elimination of tailpipe emissions and reduction of "virgin" materials exploitation. The disadvantages of in situ construction works result from the fact that these equipments can be used on roads without major structural deficiencies and for projects with a constant asphalt mixture composition [8].

Table 8 shows the costs for a HMA produced using a traditional composition and one integrating RAP. The evaluation is based on the three asphalt layers mentioned above in the paper, BA 16, BAD 25, AB 2 [12].

The prices under consideration for the analysis include the VAT. The evaluation results should be considered as informative. The values have been obtained based on unit prices offered by different Romanian companies. As comparative to the values obtained in the analysis, a distinct local company uses the following prices for the asphalt mixtures under evaluation: BA $16=74$ euro/t, $\mathrm{BAD} 25=64,5$ euro/t, $\mathrm{AB} 2=58,5$ euro/t [22]. As compared with the values offered by the company, the current analysis results are more reduced. 
During the production process, to the costs obtained, a value resulted from the product transportation can be added, around 1 euro $/ \mathrm{km}$ or 4,5 cents $/$ ton $\mathrm{x} \mathrm{km}$ or a negotiated fuel price of 1,06 euro/1 [22].

Table 8a: Cost Materials for a $1000 \mathrm{~kg}$ BA 16

\begin{tabular}{|c|c|c|c|c|c|c|c|}
\hline $\begin{array}{c}\text { BA16 } \\
\text { composition }\end{array}$ & $\%$ & $\begin{array}{c}\text { Unit price } \\
\text { euro/t } \\
\text { (VAT } \\
\text { included) }\end{array}$ & $\begin{array}{c}\text { Traditional } \\
\text { HMA } \\
\text { Euro/t on }\end{array}$ & $\begin{array}{c}\text { BA }^{\mathrm{r}} 16 \\
\text { composition }\end{array}$ & $\%$ & $\begin{array}{c}\text { Unit price } \\
\text { euro/t } \\
\text { (VAT } \\
\text { included) }\end{array}$ & $\begin{array}{c}\text { Recycled } \\
\text { HMA } \\
\text { Euro/ton }\end{array}$ \\
\hline Bitumen & 6 & 567,72 & 34,06 & BA 16 & 75 & 5 & 3,75 \\
\hline Chippings 8-16 & 24.4 & 18,17 & 4,43 & Bitumen & 2 & 567,72 & 11,35 \\
\hline Chippings 4-8 & 14.1 & 18,17 & 2,56 & Chippings 4-8 & 10 & 18,17 & 1,02 \\
\hline Crushed sand & 45.1 & 17,00 & 7,67 & Crushed sand & 10 & 17,00 & 1,7 \\
\hline Filler & 10.4 & 20,00 & 2,08 & Filler & 3 & 20,00 & 0,6 \\
\hline Total & 100 & - & $\mathbf{5 0 , 8}$ & Total & 100 & - & $\mathbf{1 8 , 4 2}$ \\
\hline
\end{tabular}

Table 8b: Cost Materials for a $1000 \mathrm{~kg}$ BAD 25

\begin{tabular}{|c|c|c|c|c|c|c|c|}
\hline $\begin{array}{c}\text { BAD 25 } \\
\text { composition }\end{array}$ & $\%$ & $\begin{array}{c}\text { Unit price } \\
\text { euro/t } \\
\text { (VAT } \\
\text { included) }\end{array}$ & $\begin{array}{c}\text { Traditional } \\
\text { HMA } \\
\text { Euro/ton }\end{array}$ & $\begin{array}{c}\text { BAD }^{\mathrm{r}} \text { 25 } \\
\text { composition }\end{array}$ & $\%$ & $\begin{array}{c}\text { Unit price } \\
\text { euro/t } \\
\text { (VAT } \\
\text { included) }\end{array}$ & $\begin{array}{c}\text { Recycled } \\
\text { HMA } \\
\text { Euro/ton }\end{array}$ \\
\hline Bitumen & 4.5 & 567,72 & 25,55 & BAD 25 & 75 & 5 & 3,75 \\
\hline $\begin{array}{c}\text { Chippings 16- } \\
25\end{array}$ & 23.9 & 16,88 & 4,03 & Bitumen & 1.2 & 567,72 & 6,81 \\
\hline Chippings 8-16 & 23.9 & 18,17 & 4,34 & Chippings 4-8 & 5 & 18,17 & 0,91 \\
\hline Chippings 4-8 & 9.4 & 18,17 & 1,71 & Chippings 8-16 & 10 & 18,17 & 1,82 \\
\hline Natural sand & 17.2 & 13 & 2,24 & Crushed sand & 5 & 17,00 & 0,9 \\
\hline Crushed sand & 16.3 & 17,00 & 2,77 & Filler & 3.8 & 20,00 & 0,76 \\
\hline Filler & 4.8 & 20,00 & 0,96 & & & & \\
\hline Total & 100 & - & $\mathbf{4 1 , 6}$ & Total & 100 & - & $\mathbf{1 4 , 9 5}$ \\
\hline
\end{tabular}

Table 8c: Cost Materials for a $1000 \mathrm{~kg} \mathrm{AB} 2$

\begin{tabular}{|c|c|c|c|c|c|c|c|}
\hline $\begin{array}{c}\mathrm{AB} 2 \\
\text { composition }\end{array}$ & $\%$ & $\begin{array}{l}\text { Unit price } \\
\text { euro/t } \\
\text { (VAT } \\
\text { included) }\end{array}$ & $\begin{array}{c}\text { Traditional } \\
\text { HMA } \\
\text { Euro/ton }\end{array}$ & $\begin{array}{c}\mathrm{AB}^{\mathrm{r}} 2 \\
\text { composition }\end{array}$ & $\%$ & $\begin{array}{l}\text { Unit price } \\
\text { euro/t } \\
\text { (VAT } \\
\text { included) }\end{array}$ & $\begin{array}{c}\text { Recycled } \\
\text { HMA } \\
\text { Euro/ton }\end{array}$ \\
\hline Bitumen & 4.2 & 567,72 & 23,84 & $\mathrm{AB} 2$ & 75 & 5 & 3,75 \\
\hline $\begin{array}{c}\text { Crushed } \\
\text { gravel 16-25 }\end{array}$ & 17.2 & 16,28 & 2,80 & Bitumen & 1.5 & 567,72 & 8,52 \\
\hline $\begin{array}{c}\text { Crushed } \\
\text { gravel 8-16 }\end{array}$ & 14.4 & 17,14 & 2,47 & $\begin{array}{c}\text { Crushed gravel } \\
4-8\end{array}$ & 6 & 16,50 & 0,99 \\
\hline $\begin{array}{l}\text { Crushed } \\
\text { gravel 4-8 }\end{array}$ & 19.2 & 16,50 & 3,17 & $\begin{array}{c}\text { Crushed gravel } \\
8-16\end{array}$ & 9 & 17,14 & 1,54 \\
\hline Natural sand & 19.2 & 13,00 & 2,50 & Crushed sand & 6 & 17,00 & 1,02 \\
\hline Crushed sand & 19.2 & 17,00 & 3,26 & Filler & 2.5 & 20 & 0,5 \\
\hline Filler & 6.6 & 20,00 & 1,32 & & & & \\
\hline Total & 100 & - & 39,36 & Total & 100 & - & 16,32 \\
\hline
\end{tabular}


The economic component of an analysis is very complex since complementary to the basic production process of traditional or recycled asphalt mixtures, must be taken into consideration several additional costs consisting of [16]:

- Investments in equipment,

- Financing possibilities,

- Maintenance of equipments,

- Quality control,

- Energy use.

Based on the available financial availabilities, on external investment opportunities, on technological developments, any company can reach the conclusion of integrating recyclability in its production process. LCC methodology can be extremely useful in finding the most profitable solution.

\section{Conclusions:}

LCA and LCC methodologies are very useful instruments to evaluate the sustainability of any company production process and to provide solution in this contect. Customized for the road construction sector this implies guiding towards selecting the materials with the lowest energy and water consumption, with minimal $\mathrm{CO}_{2} \mathrm{e}$ emissions during the product's life cycle, minimal costs and traffic disturbance. The integration of all these factors represents the criteria for selecting the most suitable pavement mixture for roads according to the approach of LCA methodology.

The present paper was focused on providing a comparative overview on the environmental and economic impact of asphalt pavements that integrate RAP. The comparisons have been made between, different types of traditional mixtures, between traditional and recycled compositions and also between countries.

Based on the analysis results, it can be concluded that the process of asphalt recycling has technical, economic and environmental benefits which refer to:

- asphalt mixtures with RAP produce the equivalent or improved performance compared with conventional asphalt mixes;

- savings can result from transporting, stockpiling, processing, handling and inventorying RAP;

- it can be obtained important reductions of environmental impacts associated with mining, decreases the depletion of aggregate reserves;

- energy savings result from the processing of less "virgin" materials, on-site recycling capabilities and reduced transportation of new materials to the site etc.

Laboratory tests suggest that the use of higher percentages of RAP is feasible and that, under specific circumstances, the recycled mixes can perform as well as the traditional ones. Cost analysis suggests significant savings due to the use of RAP mixes, resulting from savings in materials and energy costs.

Future analysis, based on LCA methodology, takes into consideration the possibility to extend the comparative analysis to other types of pavements such as flexible durable pavements as compared with classical ones. The general purpose would be to have an overview on the environmental and economic impact associated with as many asphalt pavements categories as possible and conclude on their viability from sustainability point of view.

\section{Acknowledgement}

This paper was supported by the projects: "Development and support multidisciplinary postdoctoral programs in primordial technical areas of national strategy of the research - development innovation" 4D-POSTDOC, Contract no. POSDRU/89/1.5/S/52603, project co-funded from the European Social Fund through Sectorial Operational Programme for Human Resources Development 2007-2013. 


\section{References}

[1] asPECT Protocol and Guidance Book, Transport Research Laboratory (TRL), United Kingdom, 2009, http://www.sustainabilityofhighways.org.uk.

[2] I. Al-Qadi, M. Elseifi, S. Carpenter, Reclaimed Asphalt Pavement - A Literature Review, Research Report FHWA-ICT-07-001, A report of the findings of ICT R27-11 Determination of Usable Residual Asphalt Binder in RAP, Illinois Center for Transportation, Illinois, USA, 2007,

[3] T. Al-Rousan, I. Asi, O. Al-Hattamleh, H. Al-Qablan, Performance of Asphalt Mixes Containing RAP, Jordan Journal of Civil Engineering, (2008), 218-227.

[4] FHWA (Federal Highway Administration), Asphalt Pavement Recycling with Reclaimed Asphalt Pavement (RAP), United States Department of Transportation, 2011, http://www.fhwa.dot.gov/pavement/recycling/rap/index.cfm.

[5] Five Winds International, Critical Review of the Life Cycle Assessment (LCA) Study. The Sustainability of Packaging Systems for Fruit and Vegetable Transport in Europe based on Life-Cycle-Analysis, 2011, http://www.peinternational.com/fileadmin/user_upload/news/2007/downloads/Critical_review_02.pdf.

[6] M. Hassan, SDFlex: A Framework for the Assessment and Construction of Sustainable Flexible Pavements, Journal of Green Building, 3 (2008), 108-118.

[7] A. Horvath, Life-Cycle Environmental and Economic Assessment of Using Recycled Materials for Asphalt Pavements, Technical report, 2003, www.uctc.net/papers/683.pdf.

[8] G.J. Jordaan, Life-Cycle Cost Analysis - An Integral Part of Pavement Rehabilitation Design, $10^{\text {th }}$ Conference on Asphalt Pavements for Southern Africa, 2011,

[9] P.E. Mora, Life Cycle, Sustainability and Transcendent Quality of Building Materials, Building and Environment, 42 (2007), 1329-1334.

[10] NAPA (National Asphalt Pavement Association), Recycling Hot-Mix Asphalt Pavements, IS123, Lanham, 2007,

[11] NCHRP Report 452, Recommended use of Reclaimed Asphalt Pavement in the Superpave Mix Design Method: Technician's Manual, National Research Council, National Academy Press Washington, D.C., 2001, http://www.morerap.us/files/state- practices/nchrp_rpt_452. pdf.

[12] A.M. Nicuţă, R.Frunză, Environmental Impact Assessment for traditional Versus Recycled Road Asphalt Mixtures, Environmental Engineering and Management Journal, 2012,

[13] K.A. O'Sullivan, P. Wall, The Effects of Warm Mix Asphalt Additives on Recycled Asphalt Pavement, Worcester Polytechnic Institute, Worcester, 2009,

[14] H.R. Paul, Evaluation of Recycled Projects for Performance, Proceedings of the Association of Asphalt Paving Technologists, 65 (1996), 231-254,

[15] M. Sargious, N. Mushule, Behavior of Recycled Asphalt Pavement at Low Temperatures, Canadian Journal of Civil Engineering, 18(1991), 428-435,

[16] A. Sampedro, M.A. del Val, J. Gallego, N. Querol, J. del Pozo, Huella de Carbono del Reciclado en Planta Asfaltica en Caliente con Altas Tasas de RAP, XVI CILA - Congresso Ibero-Latinoamericano do Asfalto, Brazil, 2011,

[17] A. Sampedro, M.A. del VaI. 1, N. Querol, J. del Pozo, Huella de carbono de las mezclas bituminosas, VII Jornada Nacional ASEFMA 2012,

[18] M. Tao, R. Mallick, An Evaluation of the Effects of Warm Mix Asphalt Additives on Workability and Mechanical Properties of Reclaimed Asphalt Pavement (RAP) Material, Journal of the Transportation Research Board, Washington, D.C, 2008,

[19] R. West, Reclaimed Asphalt Pavement Management: Best Practices, National Center for Asphalt Technology, NCAT Report, Auburn University, Auburn, 2010,

[20] Information on www.eapa.org,

[21] Information on www.elsan.es,

[22] Information on www.rodev.ro. 